\title{
BODY AND SENSES IN ORGANIZATIONAL RESEARCH: EMPATHIC UNDERSTANDING FROM AN EMBODIED EXPERIENCE
}

\author{
TATIANE A. FERREIRA ${ }^{1}$ \\ (iD) https://orcid.org/0000-0003-3509-0192 \\ LETÍCIA D. FANTINEL ${ }^{2}$ \\ (iD) https://orcid.org/0000-0002-4589-6352 \\ RUBENS DE A. AMARO 2 \\ (iD) https://orcid.org/0000-0003-4183-3562
}

To cite this paper: Ferreira, T. A., Fantinel, L. D., \& Amaro, R. A. (2021). Body and senses in organizational research: Empathic understanding from an embodied experience. Revista de Administração Mackenzie, 22 (5), 1-27. doi:10.1590/1678-6971/eRAMG210138

Submission: June 25, 2020. Acceptance: Nov. 18, 2020.

\footnotetext{
1 Faculty Multivix Cariacica, Cariacica, ES, Brazil.

2 Federal University of Espírito Santo (Ufes), Vitória, ES, Brazil.
}

\section{(c) $\mathrm{BY}$}




\section{ABSTRACT}

Purpose: The purpose of this paper is to discuss the contributions of the method of empathic understanding to the field of Organizational Studies by highlighting the corporeality and sensitivity of the researcher in the production and interpretation of data.

Originality/value: Since empathic understanding can be viewed as a method for analyzing the researcher's experience during fieldwork, this paper situates the role of the researcher's body as an instrument for the collection of data during their research. The theory of organizational aesthetics is taken as a basis to discuss the relevance of the sensory dimension during the research process. Without giving priority to any particular sense (such as that of sight, for example), the construction of scientific knowledge is therefore discussed in terms of the human senses that respond to diverse stimuli by highlighting the relevance of the processes involved in the production of embodied and sensible knowledge for Organizational Studies.

Design/methodology/approach: A theoretical-empirical study of qualitative nature was carried out in a street market of a Brazilian city. The method of empathic understanding directed the entire process of data collection and analysis, in which the limitations of field observations were discussed by expanding the notion of the researcher's own experience into that of a sensory experience.

Findings: The findings suggest that it is possible for the researcher to engage their mind and body during research by experiencing the field and overcoming dichotomies such as cognition/sensitivity. Such an engagement can be viewed as a major contribution of the method of empathic understanding to Organizational Studies. Thus, the notion of the body as a major vehicle for the construction of knowledge is made evident in this paper through both the discussion of the empathic understanding approach and the research carried out.

\section{KEYWORDS}

Empathic understanding. Organizational aesthetics. Sensible knowledge. Fieldwork. Qualitative methodology. 


\section{INTRODUCTION}

In the field of Organizational Studies, it is well known that discussions on reflexivity in qualitative research often highlight the importance of discussing and improving the researcher's own abilities and aptitudes to grasp the complex yet interactive and emerging nature of social experience (Cunliffe, 2003). As researchers, our attention is, thus, drawn to the so-called "nonrational" elements of organizational life, the comprehension of which has traditionally been regarded as complex and, to some extent, not treated in management and organizational studies (Warren, 2008). Yet, these elements can be made evident in the material and corporeal dimension of the organizational practice so that the focus on this dimension could represent an alternative to the hegemonic focus on the rational and cognitive aspects of a given phenomenon (Flores-Pereira, Davel, \& Almeida, 2017).

In order to engage in such problematization, the organizational aesthetics approach is used as a starting point to analyze the researcher's feelings in the understanding of the organizational practice by focusing on their tacit knowledge and sensory perceptions (Strati, 2007a). On the other hand, it should be highlighted that this approach has its origins in the search for alternative ways to construct knowledge as a response to a phenomenon regarded as a representation crisis in organizational research (Taylor \& Hansen, 2005). Such an approach is based on the so-called "epistemological metaphor" that opposes the logical-rational analysis, in which those cultures, organizational symbols, and aesthetics are taken into account in everyday life of an organization for the comprehension of the subjective experiences of their actors (Strati, 2007a).

Organizational aesthetics is closely related to sensible knowledge (Warren, 2008), which is a type of knowledge that is accessed by the senses of sight, hearing, taste, touch, and smell and is mediated by aesthetic judgment (Gherardi \& Strati, 2014; Strati, 2007a). A sense, therefore, is assigned to several meanings and levels of experience and is framed by the sensory perception of the social action and by what the Other understands and represents through language (Gherardi \& Strati, 2014). Sensible knowledge is, thus, produced and reproduced through human senses, as it is related to the actions and emotions of the organizational actors (Strati, 2007a, 2007b). For the purposes of this research, we use Strati's approach (2007a), in view of both his prevalence on the topic of organizational aesthetics and his work, which has organized this field of study with an emphasis on aspects such as 
space and organizational artifacts, in addition to his notion of art and its possible contributions to management.

By operationalizing concepts used within the approach of organizational aesthetics, Strati (2007a) proposes the empathic-aesthetic approach (which is the focus of this paper and whose implications include the researcher's understanding of the place of the other) as an action that allows the researcher to engage with the other within an organizational context and to understand their purposes, motives, and meanings. In addition, such an action can give voice to the personal aesthetic experience by (re)living the story of the Other, whether through observation or account and by involving both senses and aesthetic judgment (Strati, 2015). This is, according to the author, an immersion of the body and soul of the researcher in a journey beyond rationality that is also emotional and aesthetic. Similarly, this journey may also be made evident in the writing of the final report of the research project, as it makes use of metaphors and figurative language to describe the organizational phenomena (Strati, 2007a, 2010; Strati \& Montoux, 2002).

Lopes, Ipiranga, and Silva Junior (2017) point out that few studies analyze empathic understanding in the context of organizational analysis. In line with this interpretation, we believe that the methodological approach of empathic understanding can be further discussed in the field of Organizational Studies in view of its possible contributions to research in that field. Such contributions are made evident in terms of the possibilities of corporeality, not only through the senses involved in a research process but also through the emphasis on a type of approach that takes into account the corporeal, sensory, and material dimension of the organizational practice (Strati, 2015). And just as this approach can provide rich information for the analysis of aesthetics in organizations, working with such notions as the corporeal and the sensory in the fieldwork can be deemed as a methodological challenge, in the sense that both methodological comprehension and production of the research report imply some kind of mediation between the sensory and the cognitive (Warren, 2008).

Taking into account the points highlighted in the previous paragraph in terms of the scarce use of such an approach, in spite of its potential for the field of study, our goal is, therefore, to discuss the contributions of the method of empathic understanding to the field of Organizational Studies. In order to do so, we resort to some insights that emerged from a theoretical-empirical study carried by one of the authors of this paper in a street market of a Brazilian city, where a theoretical framework based on organizational aesthetics and a methodological approach based on empathic understanding were used. 
This research has allowed us to further advance in our inquiry by discussing the methodological implications of the dissolution of boundaries of the sensory and the cognitive domains, a topic that can be seen as a central aspect for the development of the method of empathic understanding. We argue that, beyond the conceptual overlap implied in such dissolution, the body emerges as a central vehicle for the construction of knowledge to the extent that it can be regarded as a mediator of the said processes, in spite of the fact that such a phenomenon does not follow the traditional logic of Cartesian separation. Therefore, this paper delves into organizational aesthetics to further analyze the different discussions on the methodological implications that lie at the core of empathic understanding.

\section{EMPATHIC UNDERSTANDING AND ORGANIZATIONAL AESTHETICS: ORIGINS AND DEBATES}

Empathic understanding is a method developed by Strati (2007a) as a productive alternative for the study of organizational aesthetics. Studies on organizational aesthetics emerged in the mid-1990s with the works of Antonio Strati, who proposed the mobilization of aesthetic awareness and the "epistemological metaphor" as alternatives to the logical-rational analysis traditionally favored in the understanding of organizational life through Management Studies (Ipiranga, Lopes, \& Souza, 2016; Strati, 1992). Such shift would imply taking into consideration cultures, organizational symbols, and the own aesthetics interwoven in the everyday life of an organization so that it is possible to grasp the experiences of the organizational actors (Strati, 2007a). In this regard, in addition to the logical-rational way of producing knowledge, aesthetics would enable the construction of knowledge on organizational practice by means of sensitivity.

Thus, it is possible to state that studies on organizational aesthetics favor sensible knowledge that is produced from the senses of vision, hearing, taste, touch, and smell in interaction with the aesthetic judgment of the organizational actor (Gherardi \& Strati, 2014; Strati, 2000, 2005, 2007a). It is interesting to note that, although we experience and interpret the world around us through our sensory filters, the emphasis on sensory knowledge is not usually taken into account in organizational analyses (Panayiotou, 2019).

Aesthetic judgment (or aesthetic discernment) is therefore regarded as a sixth sense that "allows us to evaluate whether something is pleasant or not; whether it suits our taste or not; whether it 'involves' us, makes us 
indifferent or even disgusts us" (Strati, 2007a, p. 11). Thus, an organizational actor makes use of their perceptual faculties and aesthetic judgment to express, through language, whether something is beautiful or ugly, good or bad, etc. (Strati, 2007a). In this context, Strati (1996) even proposes the Greek verb aisthanomai to refer to the ability to perceive through the senses and to feel through body perceptions.

Grasped through the senses and mediated by aesthetic judgment, such perceptions of the body are part of Strati's proposal (2007a) to conceive sensible knowledge as a way to understand organizational practice in a way that is directly related to the corporeality and materiality of organizational life. For Strati (2007b), sensible knowledge is concerned with three central aspects in any analysis: body and multisensorial practices, the materiality of organizational life, and aesthetic categories.

Regarding the first aspect, i.e., the body and multisensorial practices, it is worth noting that the body is a means for the realization of the aesthetic experience. In an organization, this body "is a hybrid entity composed of non-human elements that are inseparable from the person and their corporeality" (Strati, 2007a, p. 172). This being so, corporeality takes on sensible knowledge and social relations (Strati, 2010), which allows us to understand the subtleties of organizational phenomena. In this regard, by overstepping the boundaries between the material and the symbolic, we follow Bertolin, Cappelle, and Brito (2014, p. 17), for whom "the aesthetic approach breaks with the traditional mind/body dichotomy and highlights the body as a producer of knowledge".

The second aspect that of materiality is, for Strati (2008a), the distinctive character of an organization and lies within the body that thinks, judges, acts, and interacts and is also an instrument for organizational production and control. According to the author, organizational practice is permeated not only by the corporeality of the organizational actors but also by the materiality of artifacts that are thought of in their essence and their use or "being-for-use" in terms of their aesthetic characteristics. Thus, materiality beyond organizational knowledge is not solely and exclusively related to the mental dimension, but it is also corporealized in sensible knowledge (Strati, 2008b). Materiality is therefore related to the interaction between human and non-human elements.

The third aspect, referred to as aesthetic categories, has a considerable variety. Among the various categories already identified in the literature, the category of "beautiful" is the one with the highest incidence in studies, often showing itself as a near-synonym of aesthetics, style, and art in organizations 
(Hansen, Ropo, \& Sauer, 2007; Strati, 1992, 2007a). However, it is important to highlight that aesthetics is not only related to "beautiful" organizations; in fact, it comprises a range of senses and perceptions, like an unpleasant smell in the workplace, a bothering noise coming from the street etc. (Strati, 2007a). Other categories already studied deal with the sacred, the picturesque, the tragic, the ugly etc. (Strati, 2007a).

In this process of consolidation of the field, certain shared understandings are established. Among them, the main one would be that organizational practice is composed of an aesthetic dimension (already mentioned in previous paragraphs), which makes the approach of organizational aesthetics a powerful theorization to understand phenomena as distinct as leadership (Azimi, Alvedari, \& Nia, 2016; Bathurst \& Cain, 2013; Bathurst \& Kennedy, 2017; Bathurst \& Williams, 2014; Hansen et al., 2007), entrepreneurship ((Poldner, Shrivastava, \& Branzei, 2017) and organizational practices (Soares \& Bispo, 2017). Another shared understanding can be identified around the challenges in grasping this aesthetic dimension, which is not always evident and which makes the so-called traditional methodological approaches (i.e., the ones that use traditional tools of social research and are based on a rational-cognitive paradigm) relatively common in the 2000s (Taylor \& Hansen, 2005), giving increasingly more space to alternative approaches. Some authors have even resorted to the theory of organizational aesthetics to highlight the relevance of corporeality and sensible knowledge (Bathurst \& Cain, 2013; Bathurst \& Kennedy, 2017; Bertolin et al., 2014a).

In our inquiry, we replicated the same movement of return to theory in order to look for new possibilities in the methodological approach from the empathic-aesthetic perspective (Strati, 2007a, 2010; Strati \& Montoux, 2002). The understanding of aesthetic experience by such a means "consists of picturing ourselves in the place of a person whose purposes, motives and senses we wish to explain" (Strati, 2007a, p. 80). A central characteristic of the empathic-aesthetic approach is that the researcher can select a subject from the organizational scenario according to their preference and, from their senses and aesthetic judgment, engage in the activities of organizational actors in an empathic way (Strati, 2007a). This engagement with the Other in an organizational context allows the researcher to revisit their experiences and relive them when describing the collected observations so that they can turn the research data into "open text". Such style of description consists of the use of metaphors and figurative language to describe and evoke the organizational processes studied (Strati, 2007a, 2010; Strati \& Montoux, 2002). 
Empathic understanding consists, therefore, in the researcher's act of picturing himself/herself in the place of the Other whose action he wishes to explain. Yet, Ipiranga et al. (2016, p. 3) point out that there is a certain distance between intellectual and empathic understanding:

What is rationally evident is intellectually understood. And what is made evident in an empathic way is widely reexperienced. If, on the one hand, we are able to understand theorems and inferences from empirical data, on the other hand, we can only understand any errors if we have already made them. Thus, the understanding of irrational and emotional states is only possible if we ourselves, as researchers, have already experienced such states.

It should be noted that Strati (2007a) has outlined a set of propositions in relation to the operationalization of such an approach. Such propositions include the following: 1. the researcher should be willing to put himself/herself in the organizational actor's place by putting his/her empathy into practice; 2. empathic understanding requires a specific method for data collection; 3. empathic situations should be defined; 4. the architecture and the style themselves should also be defined for the description of empathy by means of an "open text"; and 5. the predominant characteristic should be identified in the knowledge production process.

From an ontological and epistemological point of view, we follow the discussion suggested by this author in the sense that, by recognizing knowledge (including the scientific one) as being sensible, the logic customarily centered on the rational and mental domains that allegedly underpins the production of knowledge, is subverted (Strati, 2007b). It is in recognition of the materiality and corporeality of human life as a central concept in such knowledge production processes - which are always situated and embodied that we can understand the existence of a certain "freedom" (especially in terms of the absence of rigid predefinitions for the rapport with the surveyed subjects) in which the researcher can feel and experience the field.

The process of knowledge production requires an intense disposition on the part of the researcher together with the activation of his/her sensory faculties (as stated in the first proposition mentioned above) so that he/she can engage him/herself in the field whose phenomenon he/she is seeking to understand. From then on, knowledge is gathered by means of self-observation, intuition, analogy, or even by reliving the aesthetic experience in imagination. After such knowledge is gathered, the situation of empathy, 
which may be the verification of a hypothesis, the sharing of experience, or the imaginative participant observation, is defined. It is then that the description of the resulting knowledge resorts to the architecture that drives the reader's imagination to live the aesthetic experience. Finally, the dominant characteristic in the process of knowledge production is elected. Such a route of empathic understanding seeks to construct a type of knowledge that is of inductive nature (Strati, 2007a) and whose components are summarized in Figure 2.1.

\section{(Figure 2.1)}

\section{COMPONENTS OF EMPATHIC UNDERSTANDING IN ORGANIZATIONS}

\section{Assumptions \\ Aspects}

1. The researcher's disposition to place himself/herself in the organizational actor's place.

Immersion in the organizational context that the researchers seek to understand

Activation of the researcher's perceptual and sensory faculties

Self-observation: deals with the researcher's need for self-observation while placing himself/herself in the Other's place

2. Methods of knowledge collection that are specific to empathy.

Intuition

Analogy

Reliving the experience in the imagination

Assumptions verification ${ }^{3}$

3. Definitions of the empathy situation

Sharing of the experience

Imaginative participant observation

4. Architecture and the style of the description

Description of knowledge in the form of an open text

5. Choice of the dominant characteristic in the knowledge construction process

Cognitive

Aesthetic

Emotional

Source: Elaborated by the authors based on Strati (2007a)

3 Though Strati (2007a) uses the term hypothesis, in this paper, we use the term "assumptions" in view of the quantitative nature of the studies involved. 
According to Strati (2007a), by engaging in empathic understanding, the researcher must be willing to perform two main actions, which are the immersion in organizational practice and the activation of perceptual and sensory faculties. Both represent the first theoretical assumption of empathic understanding. Yet, immersion in the field, specifically in the organizational practice under research, makes up the most general characteristic of empathic understanding and places the researcher beyond the formulations of a rational interpretation by engaging him/her into living and experiencing through feelings and emotions (Strati, 2007a). It is worth noting that it is necessary for the researcher to be willing to place himself/herself in the organizational actor's place. In order to do so, he/she must know the organizational context in which he/she acts. Such engagement requires the researcher to approach the ongoing event or action, since getting familiar with the Other and understanding his/her intentional action involve personal experiences that are necessary to understand the intentional action of the organizational actor (Ipiranga et al., 2016; Strati, 2007a).

\section{THE MOBILIZATION OF EMPATHIC UNDERSTANDING FOR THE PRODUCTION OF KNOWLEDGE: A STUDY AT A STREET MARKET}

The empathic understanding method was used to comprehend the different aspects of organizational life in a street flower shop. The street market where the flower shop is located is not conceived as a rigid, homogeneous, and reified organization, but in a dynamic organizational form, that is, as an organization as it happens (Schatzki, 2006). In this context, organizational aesthetics manifests itself by means of sensible knowledge, which is perceived, judged upon, produced, and reproduced through human senses, as it is related to the acts and emotional relationships of each individual (Strati, 2007a, 2007b).

For the production of the data, we used the technique of participant observation as a starting point (Serva \& Jaime, 1995). However, we believe it is important to point out that, in the context of a methodological approach guided by an aesthetic perspective that favors the different senses and not the sensible knowledge based solely on sight, being guided by observation can be semantically misleading. Indeed, one of the meanings of the word observation is "to watch someone or something carefully". That something, in this case, is the phenomenon under study. On the one hand, observation conveys 
the idea of the primacy of sight as an instrument for the production of data. On the other hand, its relevance for understanding the nuances of organizational life is undeniable mainly because, as noted by Polanyi (1966), organizational actors know more than what they are able to express; in addition to what Berger (1999, p. 9) has pointed out, "seeing precedes words". This means that the act of seeing leads us to a pre-rational experience with the world. Social subjects see things before they can even explain them with words. Thus, by joining what is seen, the field notes, and the informal conversations with the organizational actors, we can learn more about organizational life in comparison to the use of questionnaires and interviews.

However, as it has been noted, there is a semantic trick that lies in the unidimensionality that the sense of sight can represent when a technique such as observation is mobilized. In this regard, it is important to highlight Bispo's statement (2017) that we know little about the role of the researcher's body in the processes of interpreting research data. Therefore, empathic understanding should alert the researcher about the importance of paying attention to all the senses instead of relying only on what the eyes can see. In the words of Gherardi and Strati (2014, p. 27):

We have to "look with our ears" because noises are also a valuable source of information. We have to pay attention to the others; we have to see what they do, what they have made; we have to ask them how they feel; we have to exchange ideas and instructions - and lend a hand if necessary. We need our hands to do work, not to hold on to the roof. It's our legs that keep us over the roof, and we must feel they are firmly "attached to our feet".

Thus, and after much reflection, we can understand that referring to fieldwork as "observation" in empathic understanding may not be an accurate translation of the researcher's experience with the respondents. Therefore, we choose the verb "feel" instead of the usual "observe" to refer to the fieldwork undertaken during research. Furthermore, we understand that this "feeling", which is key to empathic understanding, is not limited only to the mobilization of the five senses in-field experience; rather, the verb includes the exercise of putting oneself in the other's place in the imaginary dimension, so that the senses and the aesthetic judgment are at the service of action. We understand that this exercise has five theoretical assumptions that are coordinated following a given path, as is presented in Figure 3.1. 


\section{(Figure 3.1)}

\section{THE PATH OF EMPATHIC UNDERSTANDING}

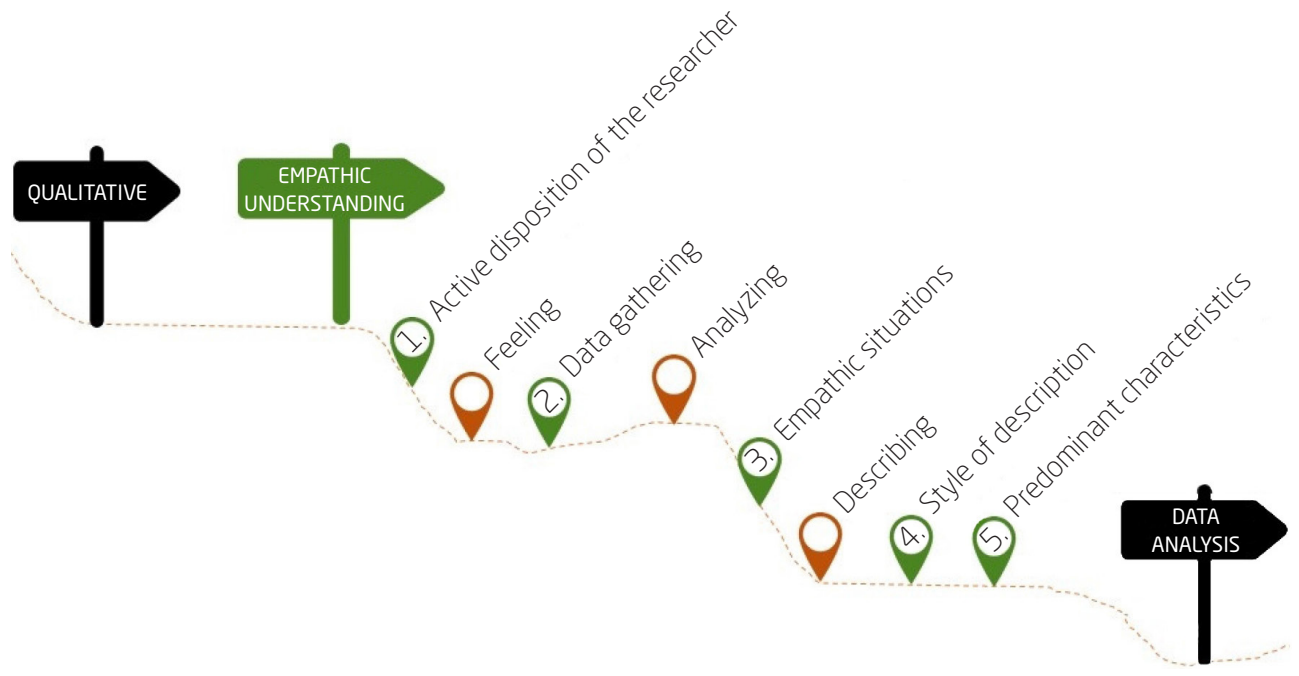

Source: Elaborated by the authors.

The figure, which is based on a qualitative approach, presents our methodological approach of empathic understanding. According to the path presented, before starting the field experience, the researcher must be willing to activate his/her sensory and perceptual faculties before the beginning of the data production and, in doing so, initiating the analysis and defining the situations of empathy. With the knowledge collected in the field, the researcher must then do the descriptions using his/her "open text" so that, in the imaginary dimension, the reader can be transported to the field that provides the information that is being narrated. Once this is done, the dominant characteristic of the information gathered is defined, and the data are, thus, ready to follow their path.

In the context of the research that defines the purpose of this paper, one of its authors stayed in the field between the months of June and September 2017, during which she made eight visits, totaling 43 hours and 55 minutes in the field. All visits were recorded in diaries by favoring the dense description (Geertz, 2008) of the information collected and organizing them by the order in which they were comprehended in the light of empathic comprehension. Diaries are very important for the process of reexperiencing the data and perceiving them from another perspective after immersion in the field. Diaries come to life in this process and, when they are revisited for 
the production of the text, the researcher's memories are activated so he/ she can relive what he/she perceived in the field. By doing so, the researcher can recapture elements that were not recorded in detail but rather lived. In the case of this co-authored paper, the diaries helped the rest of the authors in the imaginative process of putting themselves in the Other's place, considering that only one of the researchers was in the field.

The street market under study is located in one of Brazil's major cities of the Southeast Region of Brazil and has eight street flower shops which are arranged side by side. Out of all of them, seven gave their consent to participate in this research. To protect the identity of the participants and the location of their stalls in the street market under study, we used flower names to code each stall and alphanumerical codes for the names of the participants, as shown in Figure 3.2.

\section{(Figure 3.2)}

SUMMARY OF FIELD STALLS

\begin{tabular}{cllccccc}
\hline Visit & \multicolumn{1}{c}{ Date } & Stall & $\begin{array}{c}\text { No. of } \\
\text { persons }\end{array}$ & Code & $\begin{array}{c}\text { Arrival } \\
\text { time }\end{array}$ & $\begin{array}{c}\text { Exit } \\
\text { time }\end{array}$ & $\begin{array}{c}\text { Amount } \\
\text { of time in } \\
\text { the field }\end{array}$ \\
\hline 1 & $\begin{array}{c}06 / 16 / 2017 \text { and } \\
06 / 17 / 2017\end{array}$ & Alstroemeria & 3 & A1, A2, and A3 & $23: 55$ & $05: 30$ & 5.5 \\
\hline 2 & $07 / 01 / 2017$ & Alstroemeria & & & $05: 45$ & $13: 15$ & 7.5 \\
\hline 3 & $07 / 08 / 2017$ & Sunflower & 3 & G1, G2, and G3 & 06:25 & $13: 20$ & 6.9 \\
\hline 4 & $07 / 22 / 2017$ & Rose & 6 & $\begin{array}{l}\text { R1, R2, R3, R4, } \\
\text { R5, and R6 }\end{array}$ & $06: 30$ & $13: 00$ & 6.5 \\
\hline 5 & $08 / 05 / 2017$ & Anthurium & 2 & AN1 and AN2 & $08: 00$ & $13: 15$ & 5.3 \\
\hline 6 & $08 / 19 / 2017$ & Gerbera & 2 & GE1 and GE2 & $08: 40$ & $13: 00$ & 4.3 \\
\hline 7 & $08 / 26 / 2017$ & Water lilies & 2 & N1 and N2 & $09: 00$ & $13: 10$ & 4.2 \\
\hline 8 & $09 / 02 / 2017$ & Mandacaru & 2 & M1 and M2 & $09: 25$ & $13: 05$ & 3.7 \\
\hline & & Total & 20 & & & Total & 43.9 \\
\hline
\end{tabular}

Source: Elaborated by the authors.

During the study, one of the researchers of this paper got to know the pace of the field through, for example, the activities that start at dawn and end in the late morning (some of which added up to a 12-hour working day). She also got to know the lack of installations such as public toilets or the 
impossibility of performing light and heavy activities. All these findings were important for the researcher to ensure herself that she was ready for the field and that she could put herself in the organizational actor's place as, otherwise, the first theoretical assumption of empathic understanding could not be fulfilled. This immersion implied the activation of the researcher's perceptual and sensory faculties so that she could live the experience as it occurred and grasp what motivates the aesthetic action of the participant. Therefore, in addition to the disposition of the researcher to be in the field, we must add the willingness of the researcher to immerse himself/herself and activate his/her senses and feelings. This, in sum, is what it means to be body and soul in the field (Rosa \& Brito, 2010).

Another point that favors the first assumption is the familiarization that is preceded by an estrangement with the field since the unknown is being explored. Thus, the authors of this paper faced the field as anonymous individuals, yet considering the fact that they attended the said street market before in the role of either passers-by or customers, albeit not studying it previously as researchers. Thus, the path from estrangement to familiarization (Chiesa \& Fantinel, 2014) was gradually taken and was based upon sensitivity in order to know when and how to act and when to proceed with bolder actions, which eventually led the researchers to take over everyday tasks in some of the stalls in addition to establishing affective bonds with some of the stallholders.

The experience in the field is important not only for producing and recording the data to be interpreted but also for guiding the researcher on how he/she acts among those whom he/she is studying, including the moments of making use of or respecting the time of the stallholder to decide when to advance and when to withhold. Thus, the researcher can devote himself/herself to following the flow of the field (Chiesa \& Fantinel, 2014) by leaving the subjects free to speak and act. Based on these premises, the researcher of this paper gradually became comfortable enough in the field to carry out some of the regular activities of the stallholders who, in turn, responded with appreciation and gestures such as a smile or gifts such as plants, flowers, or fertilizers.

Such a familiarization helped to establish bonds between the researcher and the subjects, to the extent that sometimes the stallholders could ask the researcher in the field to take care of their stall when they needed out to go to the bathroom, eat something or make a delivery. On one occasion, the owner of one of the stalls even asked the researcher to take care of the register, which can be interpreted as an act of extreme confidence on their part. 
In addition to the activities carried out, conversations on topics other than research were held during the fieldwork period. Some stallholders even talked about their personal lives. Conversations also took place with the employees of the neighboring flower stalls, and, eventually, the researcher in the field was able to move around the stalls she had observed and establish contact with the owners of the stalls that would be observed afterward. This type of contact could also be accompanied by stallholders that would come over to the stall that was being observed. And thanks to jokes among the stallholders or some discussion in which we were invited to participate, the researcher could manage to engage herself in the next observation.

A classic example of the relationships among participants in the field and the importance of the construction of intersubjectivity during the research took place in one of the immersions. In one of them, the researcher was caught by surprise by a deep reflection on the relationship between flowers and death, due to a funeral in which the researcher had participated the day before: "At the funeral, after watching the flowers in the wreath, I stripped them from the good emotions they convey. I kept thinking that flowers are symbols that can instill good and bad feelings" (Diary 6, August 2017). Flowers, which until then used to instill feelings of pleasure in the researcher, acquired, then, new meanings in such a context. They even sparked the stallholders' imagination and thoughts when they were preparing a funeral wreath, for example. This was an empathic hypothesis formulated through the gathering of knowledge when investigating the motivation of intentional action of the organizational actor (Strati, 2007a). Such a gathering took place later in the field when the researcher empathically verified the feelings of the participant when making a funeral wreath, as described below:

I asked R2 if he knew how to make a funeral wreath. He said he knew, though he didn't like it much, and that when he had to deliver one, he preferred to ask someone to deliver it (Field diary 4, July 2017).

I asked N1 if she knew how to make a funeral wreath, and she said yes. I asked her what her feelings were when making a funeral wreath. She thought for a while before answering, went out to take care of some customers, and then came back and replied: "My feelings are just the normal ones because if I get sad for each wreath, I have to make, I cannot make ends meet" (Field diary 7, September 2017).

Initially, the notion that our feelings would always be pleasant (i.e., materialized in the aesthetic category of "beautiful", which is customarily 
present in common sense when it comes to flowers) was incorporated every time a flower arrangement was made. Besides, such a notion implied that there was no de-centering of our view in terms of imagining other types of flower arrangements, like the funeral wreaths. However, when trying to empathically understand such a feeling, it was possible to notice in the reports that the stallholders move away from the beautiful towards the ugly, not in terms of the arrangements themselves, but in terms of the situations that surround them.

Another important event was the sharing of experiences that occurred when experiencing some organizational events of the daily life of the stallholders and comprehending the burden that this represents, both physically and in terms of responsibility, as is described below:

$\mathrm{N} 1$ began to dismantle her stall and put things in big plastic boxes. She made three piles: one with four boxes, another one with three boxes, and the last one with two boxes. She turned to me and to N2 and asked: "Who is going to take the one with the three boxes and the one with the two boxes?". I promptly replied that I could take the one with the three boxes, though deep down, I was afraid of its weight. But soon, she calmed me down by saying she was going to take the boxes to the truck by dragging them along the sidewalk. So she went out pushing the big pile, and then, right behind her, it was me pushing my box. That made me happy. I felt that I was a part of it. When I was getting close to the car, she asked me if I could help her lift the big one. I grabbed it the wrong way, and it hurt my fingers a lot, but I pretended it didn't hurt. Then I helped her carrying more boxes, and she said: "That's what a stallholder's life is about. Didn't you want to study street markets? You have to feel the burden. You have to go through everything we go through" (Field diary 7, September 2017).

By experiencing the life of a stallholder, even for a short period of time, the researcher in the field was able to experience situations such as those previously reported: customer service, sales, preparation of arrangements, and movement of loads, to name but a few. In this regard, it is possible to state that "empathic understanding is only possible if the researcher has already gone through such an experience and has involved himself/herself in such a situation, which serves to postulate that what is involved is not a coincidence but rather an analogy with other situations considered as similar and familiar" (Strati, 2007a, p. 110). 
In addition, it is worth noting that empathic understanding is used for evoking and comprehending not only what is plausible, persuasive, or sayable, but also what cannot be explained, what is contradictory, what cannot be predicted, and the unsayable (Strati, 2007a). In this regard, there is the sensible knowledge needed to handle plants and flowers that are popularly referred to as "to be skilled at something" or that reveals "a talent" to grow plants: "M1 told me that [...] once he grew a little vegetable plant, and that he realized that he was good at it, and decided to grow more vegetables. Then, he began to send them to the street market and sold them very well to the extent that one day the vegetable business was replaced by plants" (Diary 8, September 2017).

Although often based on popular knowledge, the activity of growing plants has, in the aesthetic and sensory expressions of someone who is in contact with plants and flowers, the results of a good job, as is shown in the following excerpts of the field diary: "Flowers feed the soul" (Field diary 2, July 2017). "I love this stall. Its flowers are beautiful because he loves plants" and "They take care of them with affection because they [the plants] are susceptible to pests" (Field diary 8, September 2017). Another example is an expression that we coined, namely "the flower self-service", which can be used to describe the action of customers picking themselves the flowers they want to buy and making the arrangements on the go, as is shown in the following excerpt: "I noticed that the customers took the flowers from the buckets that were displayed in something like an arrangement of shapes and colors in front of the stall. It was a kind of self-service for flowers" (Field diary 2, July 2017).

These organizational excerpts serve to illustrate the interpretation of an intentional action which suggests more than it explains and which, once translated, leaves its own aesthetic essence. Metaphorically speaking, it is similar to the experience of making an arrangement in the sense that it is possible to mentally describe its process by combining colors, sizes, and shapes, but that, in doing so, the beginner's hands do not always do what his/her mind had initially projected.

\section{EXPLORING THE CONTRIBUTIONS OF THE METHOD}

Up to this section, the different forms of knowledge production have been presented based on the method of empathic understanding. We organized these forms in two central arguments: 1. the consideration of corporeal and 
material aspects as central elements in the research process; and 2. the use of imaginative resources in this process. Therefore, we consider fundamental the researcher's body and soul immersion in the flower trade at the street market along with the resource of reliving such an experience in his/her imagination.

According to Biehl-Missal (2014), both aesthetic experience and aesthetic knowledge can question, challenge, and complement the rational dimension of organizations by favoring corporeities (or corporealities) and sensitivities in the research process. Thus, we understand that empathic understanding contributes to the operationalization of the four challenges that, according to Flores-Pereira et al. (2017), are involved in the process of any academic production that seeks to consider corporealities. Such four challenges are: 1. the proximity of the researcher to the empirical field; 2. the realization of a sensory observation; 3 . the production of experiential questions during research; and 4. the production of descriptions capable of grasping the corporification of events.

Empathic understanding requires that the researcher's immersion movements in the field should be followed by efforts to relive in the imaginary dimension what was experienced. Joined to the imagination, such an exercise of observation enables a type of intellectual craftsmanship that results in a plot that Strati (2007a) defines as a sensation that connects to a thought. In the case of the study presented in this paper, the event in which the researcher in the field reflected upon the connection between flowers and death - from which new aesthetic categories emerged - was part of a movement of a symbolic distancing from the field in which possibilities from other experiences lived by this researcher emerged. Such a procedure consists of "a continuous process that includes reviewing, rereading, re-comprehension and re-argumentation" (Strati, 2007a, p. 112). The reflections produced on such movements in the field are, in the view of Flores-Pereira et al. (2017), fundamental in order to reflect on the effort that should be made to understand corporealities.

The second challenge presented here concerns the learning process involved in a sensory observation. Since the theoretical precepts of organizational aesthetics involve aspects such as materiality, sensoriality, and aesthetic categories in their fundamental dimensions, they enable the comprehension of the relationships between the researched, the researcher, and the context through empathic understanding. The researcher's immersion in the field calls for the integration of the sensory aspects in relation to the rational ones. And, since the experience of both the researcher and the researched is 
mediated by bodies, it is impracticable for the researcher to separate the sensory from the aesthetic dimension in both organizational and academic activities.

Therefore, the sensory experimentation in the field was mediated by the researcher's participation in the daily organizational tasks. The use of selfobservation, analogy, and intuition allows the reliving of the experience in the imagination. Yet, in addition to seeing through the Other's eyes, it is necessary for the researcher to put himself/herself in the shoes of those who make up the organizational scenario in order to understand and describe the aesthetic experience. The respondents' execution of both light and heavy activities, which were recorded through detailed notes and field diaries, is, as Strati (2007a) points out, essential for an adequate understanding of the organizational action.

The third challenge addressed by Flores-Pereira et al. (2017) refers to the process in which the researcher learns to construct questions for the respondents who are able to grasp their experiences and sensations. In this regard, our study followed the data collection path that is based on reliving the experience on the imaginary dimension and putting ourselves in the other's place. During the research, some of the assumptions that were made needed to be verified afterward. To this end, the researcher in the field, thus, shared experiences and inferences and pictured herself in some of the organizational actors' place. Therefore, in this study, we made use of the three definitions of empathy situation listed by Strati (2007a): verification of assumptions, sharing of experience, and imaginative participant observation. Such resources were approached in accordance with the dense observations of the field that enabled the process of producing questions, which made the respondent not only reflect on the aesthetic experience but also express their experiences and sensations.

In sum, the definitions of the situation of empathy emerged in this study through the three ways proposed by Strati (2007a): by involving the verification of assumptions to test what has taken place in the imaginary dimension, by previously living the experience of the phenomenon under study, and by seeing through Others' views related to the context under study. This fact made it possible for us to understand the organizational life as presented in the flower trade and in the detailed description of the organizational actions by reinforcing the efficiency of the method.

In the end, the challenge of learning to carry out an immediate description of the research field and providing details of the everyday events and the forms of corporification of such events (Flores-Pereira et al., 2017) was 
met through the production of a dense description which was constructed and reconstructed from the aesthetic experience and collected with the support of the method of empathic understanding. Thus, such a challenge contributed to detailed records in the field diaries, which functioned as a kind of device that activated the memory for the (re)living of episodes that were not described but rather stored in the imaginary dimension. Recorded in the field diaries, such dense description makes up the fourth assumption of empathic understanding, which is the architecture and style of the description. In this regard, Strati (2007a, p. 113) has stated that "the description must seek to merge the pathos, sensitivity, and fascination of organizational life".

\section{FINAL THOUGHTS}

In this paper, we have sought to outline the contributions of the method of empathic understanding in a research carried out at a flower stall of a street market from the point of view of the aesthetic experience as proposed by Strati (1992, 2007a). The following lines, therefore, present a synthesis of our main thoughts in this process.

First, although we have discussed empathic understanding as a research method throughout most of this paper, it should be said that its contributions also apply to epistemological aspects. These aspects emerge when the act of learning to do research using empathic understanding as a method is considered. In general, we usually treat the process of learning only in terms of its epistemological aspect - what we need to know about the method and how to apply it to understand the phenomenon under study - while ignoring its ontological dimension to which we are constantly related as researchers. This aspect of learning, which is highlighted by Brandi and Elkjaer (2011), reminds us that when we emerge in the research field, we not only affect it but we are also affected by it. In the words of Gherardi (2018), we need to remember that, as qualitative researchers, we "become with the data".

This was evident in the experience of the researcher who immersed herself in the street market, particularly in the episode of her first contact with the production of wreaths for funerals. Experiencing flowers as symbols that include seemingly opposite aesthetic categories showed that the sensory experimentation of the field, which was made possible through the use of the method, has the potential to modify impressions produced in the field itself and raise new hypotheses for investigation. Upon returning to the field and raising this point, we were able to better understand how respondents dealt 
with it in ways that had not previously emerged from the experiences in the field.

This example serves to illustrate the power of empathic understanding in comprehending certain aspects of organizational life that may be imperceptible if the researcher's sensitivity is not mobilized in the field. In this regard, the process of data production (which is not an objective reality "out there" waiting to be discovered) should be seen as an act that is fundamentally situated and embedded in historical, social, and cultural practices (Lave \& Wenger, 1991). The practices, in their turn, are conceived within a social texture that is produced by bodies and artifacts and that, therefore, cannot be accessed entirely by only the mind. Engaging - empathetically speaking with organizational actors allows us to produce what Wacquant (2015) calls carnal knowledge. This is where, in our view, lies one of the main contributions of the use of empathic understanding to Organizational Studies - to allow researchers to grasp the tacit, embodied texture of social action.

Second, we emphasize that empathic understanding reconciles the mind and the body of the researcher when doing research. Panayiotou (2019) highlights the secondary role that sensory knowledge, as related to the body and its senses, has played in organizational sciences. According to this author, even though the experience and interpretation of the world are mediated by the senses, the knowledge that comes from it is rarely considered scientific evidence per see. She highlights the ironic side of this by referring to the play on words involved in the term sensemaking. In fact, the idea that the term sense is to be understood as meaning or sense, ignoring that it also means sensation, has long been constructed and accentuated. Therefore, the process of sensemaking was taken as a purely cognitive activity.

Being in the research field, talking to participants, observing, or even taking part in their activities are not solely mental or out-of-body experiences. As Bispo and Gherardi (2019) explain, even cognition is a situated and embodied activity. It is situated because the researcher's thinking and reflecting both affect and are affected by the field and involves actions, feelings and emotions. In addition, cognition is embodied because our body is a biological entity that is developed socially. Therefore, immersion in the field does not produce disembodied knowledge. Doing research is not separate from knowing (Gherardi \& Perrota, 2014). Knowledge is produced because there is an engagement of the body within the research. As stated by Bispo and Gherardi (2019), the researcher's interpretation and judgment depend on his/her ability to perceive his/her body. In this regard, doing research implies not only mental but also corporeal and embodied learning. The body 
can, therefore, be more aware and open to learning in research when empathic understanding as a method is adopted. In this regard, we reiterate the dissolution of the alleged boundaries between the domains of the sensory and the cognitive, since the body is configured as a central vehicle for the production of knowledge, something that is even more evident in discussions on the approaches to empathic understanding.

Third, we agree with Bispo and Gherardi's (2019) statement that qualitative researchers tend to pay special attention to the role of their bodies in terms of "being in the field" and "collecting data". In fact, these authors raise a question that requires an honest answer: what is the place of the researcher's body when he/she analyzes the data produced in the field? In such stage of the research, the role of the mind is emphasized, considering that the most frequently used words to translate the actions are "reflection" and "analysis". The awareness of the physical activities of the research fades in the readings and re-readings of the field notes. In this regard, we emphasize the importance of empathic understanding not only as a method but also as a research posture. Revisiting field notes using imaginary participatory observation (Strati, 2007a) makes us aware of the role of our body in research. By assuming this posture, we are imbued with emotions and feelings that nourish our cognition by reconciling body and mind when analyzing the data. Finally, we believe that empathic understanding as a research posture has an enormous potential to contribute to other qualitative research methods.

\section{CORPO E SENTIDOS NA PESQUISA ORGANIZACIONAL: A COMPREENSÃO EMPÁTICA A PARTIR DE UMA EXPERIÊNCIA ENCARNADA}

RESUMO

Objetivo: Este artigo objetiva discutir as contribuições do método da compreensão empática para o campo da pesquisa nos Estudos Organizacionais, evidenciando a corporalidade e sensibilidade do pesquisador na produção e interpretação dos dados.

Originalidade/valor: Considerando que a compreensão empática é um método que centraliza a preocupação na experimentação sensível do campo por parte do pesquisador, a contribuição deste texto reside em situar o corpo como instrumento de produção dos dados na prática da 
pesquisa. Tomamos como base a teoria da estética organizacional para abordar a dimensão do sensível nesse processo. Discutimos, assim, a construção do conhecimento científico a partir dos sentidos humanos que captam estímulos de naturezas diversas, sem dar ênfase específica a um ou outro sentido (como a tradicional observação), destacando a importância dos processos de produção de conhecimento encarnado e sensível em Estudos Organizacionais.

Design/metodologia/abordagem: Partimos de um estudo teórico-empírico de natureza qualitativa desenvolvido em uma feira livre de uma capital brasileira. O método da compreensão empática guiou todo o processo de produção e tratamento dos dados, em que refletimos sobre as limitações do observar o campo, ampliando a experiência do pesquisador para uma noção de experimentação sensível.

Resultados: A discussão proposta permite reconciliar mente e corpo do pesquisador ao realizar a investigação, experimentando o campo e rompendo com dicotomias entre o domínio do cognitivo e o sensível, o que entendemos ser a principal contribuição do método para o campo dos Estudos Organizacionais. Nesse sentido, reiteramos o corpo como veículo central da produção do conhecimento, algo que fica evidente nas discussões sobre a abordagem da compreensão empática e na pesquisa realizada.

\section{PALAVRAS-CHAVE}

Compreensão empática. Estética organizacional. Conhecimento sensível. Pesquisa de campo. Metodologia qualitativa.

\section{REFERENCES}

Azimi, B. S., Alvedari, H., \& Nia, S. H. (2016). Studying effects of aesthetic leadership on customer experience management in Karaj chain stores, Iran. Conference on Knowledge Management, 8, Tehran, Iran.

Bathurst, R., \& Cain, T. (2013). Embodied leadership: The aesthetics of gesture. Leadership, 9(3), 358-377. doi:doi.org/10.1177/1742715013485851

Bathurst, R., \& Kennedy, F. (2017). Hunting the "play': A leadership suite in 12 movements. Leadership, 13(1), 20-34. doi:10.1177/1742715016654000 
Bathurst, R., \& Williams, L. P. (2014). Getting to performance: NZTrio and relational dynamics. Organizational Aesthetics, 3(1), 65-78.

Berger, J. (1999). Modos de ver. Rio de Janeiro: Rocco.

Bertolin, R. V., Cappelle, M. C. A., \& Brito, M. J. de (2014). Corporeidade e estética na aprendizagem organizacional: Insights emergentes. Revista de Administração Mackenzie, 15(2), 15-37. doi:10.1590/S1678-69712014000 200002

Biehl-Missal, B. (2014). "I write like a painter": Feminine creation with artsbased methods in organizational research. Gender, Work and Organization, 22 (2), 179-196. doi:10.1111/gwao.12055

Bispo, M. D. S. (2017). Educating qualitative researches in management. Revista de Administração de Empresas, 57(2), 158-169. doi:10.1590/s0034759020170205

Bispo, M. D. S., \& Gherardi, S. (2019). Flesh-and-blood knowing interpreting qualitative data through embodied practice-based research. RAUSP Management Journal, 54(4), 371-383. doi:10.1108/rausp-04-2019-0066

Brandi, U., \& Elkjaer, B. (2011). Organizational learning viewed from a social learning perspective. In M. Easterby-Smith \& M. A. Lyles (Eds.), Handbook of organizational learning \& knowledge management (2nd ed.). Hoboken, NJ: Wiley.

Chiesa, C. D., \& Fantinel, L. D. (2014). "Quando eu vi, eu tinha feito uma etnografia": Notas sobre como não fazer uma "etnografia acidental". Anais do Encontro de Estudos Organizacionais da Anpad, 8, Gramado.

Cunliffe, A. L. (2003). Reflexive inquiry in organizational research: Questions and possibilities. Human Relations, 56 (8), 983-1003. doi:10.1177/ 00187267030568004

Flores-Pereira, M. T., Davel, E., \& Almeida, D. D. de (2017). Desafios da corporalidade na pesquisa acadêmica. Cadernos EBAPE.BR, 15(1), 194-208. doi:10.1590/1679-395149064

Geertz, C. (2008). Uma descrição densa: Por uma teoria interpretativa da cultura. In C. Geertz, A interpretação das culturas (pp. 3-21). Rio de Janeiro: LTC.

Gherardi, S. (2018). Theorizing affective ethnography for organization studies. Organization, 26(6), 741-760. doi:doi.org/10.1177/1350508418805285

Gherardi, S., \& Perrota, M. (2014). Between the hand and the head: How things get done, and how in doing the ways of doing are discovered. Qualitative Research in Organizations and Management, 9(2), 134-150. doi:10.1108/QROM-06-2012-1079 
Gherardi, S., \& Strati, A. (2014). Administração e aprendizagem na prática. São Paulo: Elsevier.

Hansen, H., Ropo, A., \& Sauer, E. (2007). Aesthetic leadership. Leadership Quarterly, 18(6), 544-560. doi:10.1016/j.leaqua.2007.09.003

Ipiranga, A. S. R., Lopes, L. L. S., \& Souza, E. M. de (2016). A experiência estética nas práticas culinárias de uma organização gastronômica. Organizações $\mathcal{E}$ Sociedade, 23(77), 191-210. doi:10.1590/1984-9230771

Lave, J., \& Wenger, E. (1991). Situated learning: Legitimate peripheral participation. Cambridge, UK: Cambridge University Press.

Lopes, L. L. S., Ipiranga, A. S. R., \& Silva, J. J. da, Junior (2017). Compreensão empática e as possíveis contribuições para a pesquisa nos estudos organizacionais: Reflexões a partir da experiência do lado estético das organizações. Cadernos EBAPE.BR, 15(4), 831-845. doi:10.1590/1679-395155010

Panayiotou, A. (2019). Introduction to the virtual special issue on sensory knowledge. Management Learning, Virtual Special Issue.

Polanyi, M. (1966). The tacit dimension. London: Routdedge \& Kegan Paul.

Poldner, K., Shrivastava, P., \& Branzei, O. (2017). Embodied multi-discursivity: An aesthetic process approach to sustainable entrepreneurship. Business $\mathcal{E}$ Society, 56(2), 214-252. doi:10.1177/0007650315576149

Rosa, A. R., \& Brito, M. J. de (2010). "Corpo e alma” nas organizações: Um estudo sobre dominação e construção social dos corpos na organização militar. Revista de Administração Contemporânea, 14(2), 194-211.

Schatzki, T. R. (2006). On organizations as they happen. Organization Studies, 27(12), 1863-1873. doi:10.1177/0170840606071942

Serva, M., \& Jaime, P., Júnior (1995). Observação participante pesquisa em administração: Uma postura antropológica. Revista de Administração de Empresas, 35(3), 64-79.

Soares, L. C., \& Bispo, M. de S. (2017). A aprendizagem do cozinhar à luz das práticas sociais e da estética organizacional. Brazilian Business Review, 14(2), 247-271. doi:10.15728/bbr.2017.14.2.6

Strati, A. (1992). Aesthetic understanding of organizational life. Academy of Management Review, 17(3), 568-581. doi:10.2307/258723

Strati, A. (1996). Organizations viewed through the lens of aesthetics. Organization, 3(2), 209-218. doi:10.1177/135050849632004

Strati, A. (2000). Putting people in the picture: Art and aesthetics in photography and in understanding organizational life. Organization Studies, $21(\mathrm{X})$, 53-69. doi:10.1177/0170840600210004 
Strati, A. (2005). Designing organizational life as "aesth-hypertext": Insights to transform business practice. Organization, 12(6), 919-923. doi:10.1177/ 1350508405057476

Strati, A. (2007a). Organização e estética (P. M. Soares, Trad.). Rio de Janeiro: FGV.

Strati, A. (2007b). Sensible knowledge and practice-based learning. Management Learning, 38(1), 61-77. doi:10.1177/1350507607073023

Strati, A. (2008a). "Dietro le quinte": La ricerca qualitativa sulla dimensione estetica dell' organizzazione. In R. Cipriani. L'analisi qualitativa. Teorie, metodi, applicazioni (pp.73-88). Roma: Armando Editore.

Strati, A. (2008b). Aesthetics of organization. In S. Clegg, R. Stewart, J. R. Bailey. International encyclopedia of organization studies (pp. 38-39). California: Sage.

Strati, A. (2010). Aesthetic understanding of work and organizational life: Approaches and research developments. Sociology Compass, 10, 880-893. doi:10.1111/j.1751-9020.2010.00323.x

Strati, A. (2015). Ordinary beauty and aesthetic research in organization studies. In J. Przychodzen, F.-E. Boucher, \& S. David (Dir.), L'esthétique du beau ordinaire dans une perspective transdisciplinaire. Ni du gouffre ni du ciel (pp. 79-93). Paris: l'Harmattan.

Strati, A., \& Montoux, P. G. de. (2002). Introduction: Organizing aesthetics. Human Relations, 55(7), 755-766.

Taylor, S. S., \& Hansen, H. (2005). Finding form: Looking at the field of organizational aesthetics. Journal of Management Studies, 42 (6), 1211-1231. doi:10.1111/j.1467-6486.2005.00539.x

Wacquant, L. (2015). For a Sociology of flesh and blood. Qualitative Sociology, 38(1), 1-11. doi:10.1007/s11133-014-9291-y

Warren, S. (2008). Empirical challenges in organizational aesthetics research: Towards a sensual methodology. Organization Studies, 29(4), 559-580. doi: $10.1177 / 0170840607083104$

Tatiane A. Ferreira, master from the Center for Legal and Economic Sciences, Federal University of Espírito Santo (Ufes); Letícia D. Fantinel, Ph.D. from the Postgraduate Center in Management, Federal University of Bahia (UFBA); Rubens A. Amaro, Ph.D. from the Graduate Program in Business Administration, Mackenzie Presbyterian University (UPM). 
Tatiane A. Ferreira is now a professor at the Department of Management and Accounting of the Faculty Multivix Cariacica; Letícia D. Fantinel is now a professor at the Graduate Program in Business Administration of Ufes; Rubens A. Amaro is now a professor at the Graduate Program in Business Administration of Ufes.

Correspondence concerning this article should be addressed to Letícia D. Fantinel, Avenida Fernando Ferrari, 514, Goiabeiras, Vitória, Espírito Santo, Brazil, CEP 29075-910.

E-mail: leticia.fantinel@ufes.br

\section{EDITORIAL BOARD}

\section{Editor-in-chief}

Gilberto Perez

\section{Associate editor}

Renata Silva de Carvalho Chinelato

Technical support

Vitória Batista Santos Silva

\section{EDITORIAL PRODUCTION}

Publishing coordination

Jéssica Dametta

Language editor

Daniel de Almeida Leão

Layout designer

Emap

Graphic designer

Libro 